\title{
Analisa Strategi Promosi Dinas Pariwisata dan Kebudayaan dalam Meningkatkan Jumlah Kunjungan Wisatawan di Kabupaten Kerinci
}

\author{
Edia Satria
}

STIE Sakti Alam Kerinci

\begin{abstract}
This research was conducted to find out and prove empirically promotion strategies of cultural tourism and in increasing the number of tourists visit Kerinci Regency. Source data obtained from the Department of tourism and culture District Kerinci. Data analysis tools by using SWOT analysis. The research results obtained that (1) the cultural and Tourism Office of District 1 quadrant is at Kerinci (positive, positive) which means the primacy of kompotitif or aggressive strategies of Cultural tourism and the Regency of Kerinci has the power as well as opportunities to continue to improve and enlarge the number of promotional visits to the Regency of Kerinci; and (2) the right marketing strategies applied to Kerinci District Tourism Office for the moment is a strategy SO (strength, Opportunities). This strategy is underway to harness the power for the menagkap opportunities that are owned. As for the strategies that can be applied include (a) the Kerinci Regency Tourism Office must keep working to develop tourism in Kerinci Regency; (b) Tourism District's tourism should control Keerinci well; (c) the coordination of Tourism with Government Kabuapeten Kerinci must continue to be improved; $(d)$ the Services provided should be constantly improved; and (e) to add visits to the County of Kerinci, tourism and Culture must make use of technology and facilities available, doing promotions, and socialization as many to the community to reach.
\end{abstract}

Keywords: Promotion Strategy

\section{PENDAHULUAN}

Kebutuhan Manusia ada kebutuhan akan sandang, pangan dan papan sampai lain pada kebutuhan seperti, Pendidikan, Kesehatan, Keamanan bahkan Rekreasi. Kebutuhan Manusia akan rekreasi muncul sehubungan dengan kehidupan sehari-hari setiap Manusia tidak terlepas dari kegiatan rutinitas yang dijalaninya baik dirumah atau ditempat lain. Kegiatan pada satu titik tertentu diwaktu tertentu akan menimbulkan kejenuhan, sehingga manusia akan berusaha untuk berhenti atau meninggalkan kegiatan-kegiatan rutinnya itu untuk mencari seling untuk menghibur dirinya, memperoleh kesenangan dan kembali menyegarkan diri. Salah satunya melallaui rekreasi. Dalam rangka memenuhi kebutuhan manusia akan rekreasi maka akan berkembanglah apa yang disebut pariwisata dibanyak Negara Dunia. Di Indonesia pariwisata mulai menujukkan perkembangan yang signifikan pada tahun 1990-an. Pada waktu itu perdagangan sektor migas didunia internasional kian merosot, padahal indonesia mengandalkan sektor migas ini untuk pembiayaan pembangunan. Maka dicarilah alternatif ain diluar sektor migas non migas untuk pembiayaan pembangunan yaitu sektor pariwisata.

Promosi merupakan salah satu bagian dari rangkaian kegiatan pemasaran suatu barang. Promosi adalah suatu kegiatan bidang 


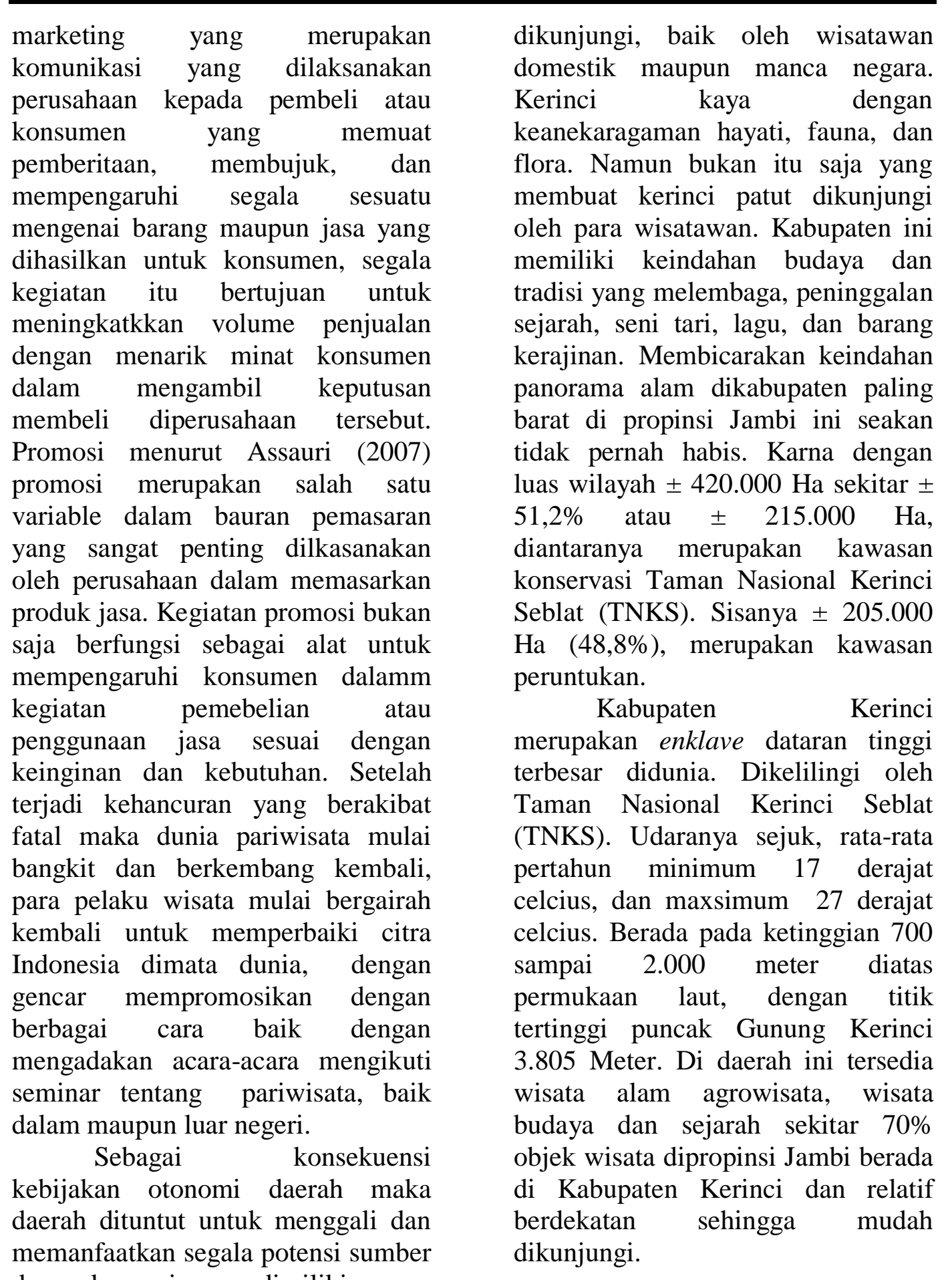

daya ekonomi yang dimiliki secara optimal dalam rangka menjamin keberlangsungan pembangunan di daerah, baik potensi sumber daya alam, sumber daya manusia maupun potensi ekonomi lainnya. Kabupaten Kerinci yang terletak 425 kilometer dibarat kota Jambi adalah karunia tuhan yang tiada terhingga, daerah ini memiliki puluhan objek wisata yang sangat menarik untuk

\section{Tabel 1}

\section{Wisata di Kabupaten Kerinci}

\begin{tabular}{|l|l|}
\hline No & \multicolumn{1}{|c|}{ Nama Wisata } \\
\hline 1. & Air Terjun Teluk Berasap \\
\hline 2. & Gunung Tujuh \\
\hline 3. & Danau Kaco \\
\hline 4. & Danau Kerinci \\
\hline 5. & Danau Lingkat \\
\hline 6. & Air Terjun Talang Kemulun \\
\hline 7. & Air Terjun Pancaran Rayo \\
\hline
\end{tabular}




\begin{tabular}{|l|l|}
\hline 8. & Air Panas Semurup \\
\hline 9 & Gunung Kerinci \\
\hline 10 & Danau Lingkat \\
\hline
\end{tabular}

Sumber: Dinas Pariwisata dan

Pendidikan Kabupaten Kerinci

Faktor-faktor yang penunjang antara lain bandara Depati Parbo, sarana transformasi, jasa penginapan dan restoran jalur lintas yang strategis yang menghubungkan kotakota besar, daerah-daeeah, dan desadesa yang sera sarana komunikasi yang memadai. Pengembangan terhadap sektor ini telah menyumbangkan sejumlah penambahan bagi pendapatan daerah. Sumbangan yang diberikan masih minim seperti industri pengelolaan dan perdagangan, sehingga perlu usaha pengembangan yang lebih instensif agar kunjungan wisatawan diKabupaten Kerinci terus meningkat.

Kabupaten kerinci berada dibawah wewenang dinas pariwisata dan kebudayaan. Dinas ini merupakan pihak yang bertanggungjawab terhadap terencanaan, pengembangan, serta peraturan dan mengadakan pembinaan terhada industri kepariwisataan didaerah secara menyeluruh. Dalam menjalankan tugasnya dinas ini memandang perlu adanya rencana strategis yang handal untuk menhadapi perubahan yang terjadi didunia pariwisata dan pemasaran serta peningkatan kunjungan wisatawan baik domestik maupun wisatawan asing ke Kabupaten Kerinci. Ttujuan penelitian ini adalah untuk mengetahui berapa besar peluang pasar dan strategi pemasaran yang dilaksanakan pada Dinas Pariwisata dan Kebudayaan dalam meningkatkan jumlah kunjungan wisatawan di Kabupaten Kerinci

\section{Tinjauan Pustaka \\ Strategi Pemasaran}

Proses penerapan strategi pemasaran mengharuskan marketer untuk mengidentifikasi kebutuhan dan keinginan pelanggan - pasar sasaran, memuaskan pelanggan (lebih tinggi dari pesaing), dan menjaga pelanggan sebagai sarana untuk keberlanjutan profit (Hasan, 2013:4) Menurut Hasan (2013:436), strategi pemasaran yang baik harus dibangun atas dasar pemahaman bisnis yang kuat, dikombinasikan dengan pemahaman kebutuhan dan keinginan pelanggan, pesaing dan skills, dan core bisnis termasuk dengan para pemasok dan distributor. Di semua tipe bisnis, tiga langkah berikut ini dapat membantu dalam mencapai keberhasilan: (1) pelajari pelanggan dan pasar untuk mengetahui produk dan jasa apa yang dapat menciptakan nilai ekonomis; (2) kembangkan segmentasi yang mencerminkan daya tarik ekonomis bagi pelanggan; dan (3) kembangkan nilai yang jelas bagi setiap segmen.

Ciri penting rencana strategis pemasaran menurut Sofyan Assauri (2008:183) adalah: (1) titik tolak penyusunannya melihat perusahaan secara keseluruhan; (2) diusahakan dampak kegiatan yang direncanakan bersifat menyeluruh; (3) dalam penyusunannya diusahakan untuk memahami kekuatan yang mempengaruhi perkembangan perusahaan; (4) jadwal dan waktu (timing) yang ditentukan adalah yang sesuai dan mempertimbangkan fleksibilitas dalam menghadapi perubahan; dan (5) penyusunan rencana dilakukan secara realistis dan relevan dengan lingkungan yang dihadapi.

\section{Jenis-jenis Strategi Pemasaran}

Dalam hubungan strategi 


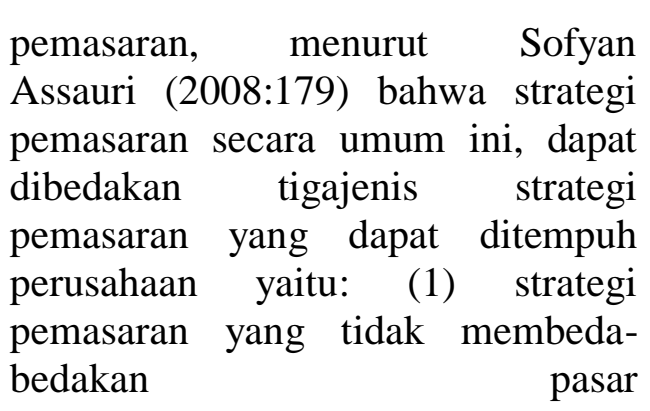

(Undifferentiatedmarketing);

strategi pemasaran yang membedabedakan

pasar

(Differentiatedmarketing); dan (3) strategi pemasaran yang terkonsentrasi (Concentrated Marketing).

Untuk lebih jelasnya ketiga jenis strategi pemasaran di atas dapat diuraikan sebagai berikut:

1. Strategi pemasaran yang tidak membeda-bedakan pasar (Undifferentiatedmarketing).

Dengan strategi ini, perusahaan menganggap pasar sebagai suatu keseluruhan, sehingga perusahaan hanya memperhatikan kebutuhan konsumen secara umum, Oleh karena itu perusahaan hanya menghasilkan dan memasarkan satu macam produk saja dan berusaha menarik semua pembeli dan calon pembeli dengan suatu rencana pemasaran saja. Strategi ini bertujuan untuk melakukan penjualan secara massal, sehingga menurunkan biaya. Perusahaan memusatkan perhatiannya pada seluruh konsumen dan kebutuhannya, serta merancang produk yang dapat menarik sebanyak mungkin para konsumen tersebut Perusahaan yang menggunakan strategi ini, tidak menghiraukan adanya kelompok pembeli yang berbeda-beda. Pasar dianggap sebagai suatu keseluruhan dengan ciri kesamaan dalam kebutuhannya. Salah satu keuntungan strategi ini adalah kemampuan perusahaan untuk menekan biaya sehingga dapat lebih ekonomis. Sebaliknya, kelemahannya adalah apabila banyak perusahaan lain juga menjalankan strategi pemasaran yang sama, maka akan terjadi persaingan yang tajam untuk menguasai pasar tersebut (hypercompetition), dan mengabaikan segmen pasar yang kecil lainnya.Akibatnya, strategi ini dapat menyebabkan kurang menguntungkannya usaha-usaha pemasaran perusahaan, karena banyak dan makin tajamnya persaingan.

2. Strategi pemasaran yang membeda-bedakan pasar (Differentiatedmarketing).

Dengan strategi ini, perusahaan hanya melayani kebutuhan beberapa kelompok konsumen tertentu dengan jenis produk tertentu pula Jadi perusahaan atau produsen menghasilkan dan memasarkan produk yang berbeda-beda untuk tiap segmen pasar. Dengan perkataan lain, perusahaan atau produsen menawarkan berbagai variasi produk dan product mix, yang disesuaikan dengan kebutuhan dan keinginan kelompokkonsumen atau pembeli yang berbeda-beda, dengan program pemasaran yang tersendiri diharapkan dapat dicapai tingkat penjualan yang tertinggi dalam masing-masing segmen pasar tersebut Perusahaan yang menggunakan strategi ini bertujuan untuk mempertebal kepercayaan kelompok konsumen tertentu terhadap produk yang dihasilkan dan dipasarkan, sehingga pembeliannya akan dilakukan berulang kali. Dengan demikian 
diharapkan penjualan perusahaan akan lebih tinggi dan kedudukan produk perusahaan akan lebih kuat atau mantap di segmen pasar. Keuntungan strategi pemasaran ini, penjualan dapat diharapkan akan lebih tinggi dengan posisi produk yang lebih baik di setiap segmen pasar, dan total penjualan perusahaan akan dapat ditingkatkan dengan bervariasinya produk yang ditawarkan. Kelemahan strategi ini adalah, terdapat kecenderungan biaya akan lebih tinggi karena kenaikan biaya produksi untuk modifikasi produk, biaya administrasi, biaya promosi, dan biaya investasi.

3. Strategi pemasaran yang terkonsentrasi (Concentrated marketing)

Dengan strategi ini, perusahaan mengkhususkan pemasaran produknya dalam beberapa segmen pasar, dengan pertimbangan keterbatasan sumberdaya perusahaan. Dalam hal ini perusahaan produsen memilih segmen pasar tertentu dan menawarkan produk yang sesuai dengan kebutuhan dan keinginan kelompok konsumen yang ada pada segmen pasar itu, yang tentunya lebih spesifik. Strategi pemasaran ini mengutamakan seluruh usaha pemasaran pada satu atau beberapa segmen pasar tertentu saja Jadi perusahaan memusatkan segala kegiatan akan memberikan keuntungan yang terbesar. Keuntungan penggunaan strategi ini, perusahaan dapat diharapkan akan memperoleh kedudukan atau posisi yang kuat di dalam segmen pasar tertentu yang dipilih. Hal ini karena, perusahaan akan mempunyai pengetahuan dan pengalaman yang lebih baik dalam melakukan pendekatan bagi pemenuhan kebutuhan dan keinginan konsumen dari segmen pasar yang dilayaninya. Di samping itu perusahaan memperoleh keuntungan karena spesialisasi dalam produksi, distribusi dan usaha promosi, sehingga apabila segmen pasar dipilih secara tepat, akan dapat memungkinkan berhasilnya usaha pemasaran produk perusahaan tersebut Kelemahan strategi pemasaran ini adalah perusahaan akan menghadapi risiko yang besar bila hanya tergantung pada satu atau beberapa segmen pasar saja. Hal ini karena, kemungkinan terjadinya perubahan selera para konsumen, atau peningkatan kemampuan daya saing perusahaan lain yang dapat melebihi kemampuan perusahaan ini dalam melayani pasar secara baik dan efektif.

\section{Bauran Pemasaran}

Menurut Yoeti (2006:22) pemasaran adalah pertukaran barang dan jasa untuk memenuhi atau memuaskan kebutuhan dan keinginan. Barang dan jasa dapat di pertukarkan dengan uang, atau jasajasa lain asal dapat memenuhi kebutuhan dan keinginan konsumen. Menurut Lupiyoadi dan Hamdani (2009: 70-76) unsur bauran pemasaran ini meliputi:

1. Product (produk)

Merupakan keseluruhan konsep objek atau proses yang memberikan sejumlah nilai kepada konsumen. Yang perlu diperhatikan dalam produk adalah konsumen tidak hanya 
membeli fisik dari produk itu saja tetapi membeli manfaat dan nilai dari produk tersebut. Keunggulan produk jasa terletak pada kualitasnya, yang mencakup keandalan, ketanggapan, kepastian, dan empati. Kembangkan nilai tambah produk selain keistimewaan dasarnya, agar dapat dibedakan dengan produk lain dan memiliki citra tersendiri. Dengan demikian, produk akan mampu bersaing.

2. Price (harga)

Sangat signifikan dalam pemberian nilai kepada konsumen dan mempengaruhi citra produk, serta keputusan konsumen untuk membeli. Penentuan harga juga berhubungan dengan pendapatan dan turut mempengaruhi penawaran atau saluran pemasaran.

3. Place (tempat)

Dalam jasa merupakan gabungan antara lokasi dan keputusan atas saluran distribusi, dalam hal ini berhubungan dengan bagaimana cara penyampaian jasa kepada konsumen dan dimana lokasi yang strategis.

4. Promotion (promosi)

Promosi merupakan salah satu variabel dari bauran pemasaran yang sangat penting dilaksanakan oleh perusahaan dalam memasarkan produk jasa. Kegiatan promosi berfungsi sebagai alat untuk mempengaruhi konsumendalam kegiatan pembelian atau penggunaan jasa sesuai dengan keinginan dan kebutuhannya.

5. People (orang)

Dalam hubungannya dengan pemasaran jasa maka orang yang berfungsi sebagai penyedia jasa sangat mempengaruhi kualitas jasa yang diberikan. Keputusan dalam „orange ini berarti berhubungan dengan seleksi, pelatihan, motivasi, dan manajemen sumber daya manusia.

6. Process (proses)

Merupakan gabungan dari semua aktivitas, umumnya terdiri atas prosedur, jadwal pekerjaan, mekanisme, aktivitas, dan hal-hal rutin, di mana jasa dihasilkan dan disampaikan kepada konsumen. Proses dapat dibedakan dalam dua cara yaitu: a) kompleksitas, berhubungan dengan langkah-langkah dan tahapan proses; dan b) keragaman, berhubungan dengan adanya perubahan dalam langkah-langkah atau tahapan proses.

7. Customer service (layanan konsumen)

Layanan konsumen dalam pelayanan jasa lebih dilihat sebagai hasil dari kegiatan distribusi dan logistik, dimana pelayanan diberikan kepada konsumen untuk mencapai kepuasan. Layanan konsumen meliputi aktivitas untuk memberikan kegunaan waktu dan tempat termasuk pelayanan pratransaksi, saat transaksi, dan pasca transaksi.

\section{Bauran Promosi ( Promotion Mix ).}

Menurut Yoeti (2006: 237) yang dimaksud dengan promosi adalah suatu cara menginformasikan atau memberitahukan kepada calon pembeli tentang produk/ jasa yang ditawarkan dengan memberitahukan tempat-tempat dimana orang dapat melihat atau melakukan pembelian pada in the right place and at the right time. Sedangkan promosi 
pariwisata merupakan kegiatan komunikasi pemasaran yaitu penyampaian pesan-pesan pemasaran dalam segala bentuk yang bertujuan memelihara dan meningkatkan dan memantapkan citra pariwisata serta membantu upaya penjualan. Promosi terbagi atas promosi dalam negeri dan promosi luar negeri. Promosi dalam negeri yaitu suatu usaha menawarkan produk pariwisata Kabupaten Kerinci kepada wisatawan agar dapat menikmati produk pariwisata yang ada kabupaten Kerinci dengan sasaran yaitu wisatawan domestik.

Promosi luar negeri yaitu suatu usaha melalui beberapa kegiatan ( mengikuti travel fair di luar negeri, dan bursa pariwisata ) dalam rangka memperkenalkan objek wisata dan daya tarik wisata di Kabupaten kerinci kepada wisatawan mancanegara (asing) agar tertarik untuk berkunjung ke Kabupaten kerinci Dalam pemasaran wisata kegiatan promosi mempunyai peranan penting dan menentukan untuk berhasilnya upaya menciptakan permintaan atau tergeraknya calon-calon wisatawan untuk melakukan perjalanan wisata ke Kabupaten kerinci.

1. Advertising (Periklanan) Advertising adalah jenis komunikasi pemasaran, yang merupakan istilah umum yang mengacu kepada semua bentuk teknik komunikasi yang digunakan pemasar untuk menjangkau konsumennya dan menyampaikan pesannya. . Moriarty, dkk ( 2011: 6 ).

2. Personal Selling ( Penjualan Perseorangan )

Sifat penjualan perorangan dapat dikatakan lebih luwes karena tenaga penjualan dapat secara langsung menyesuaikan penawaran penjualan dengan kebutuhan dan perilaku masingmasing calon pembeli. Lupiyoadi dan Hamdani ( 2009: 121 ).

3. Sales Promotion ( Promosi Penjualan )

American Marketing Association memberikan definisi Promosi penjualan dalah penekanan pemasaran media dan non media yang diiaplikasikan untuk periode waktu yang tak ditentukan sebelumnya dan terbatas pada level konsumen, retail, atau grosir dalam rangka menstimulasi tindakan mencoba produk, meningkatkan permintaan konsumen, atau meningkatkan ketersediaan produk. dalam Moriarty, dkk ( 2011: 586 ).

4. Public Relation ( Hubungan Masyarakat )

Public relation adalah fungsi manajemen yang membangun dan menjaga hubungan yang saling menguntungkan antara organisasi dan publik yang menjadi dasar kesuksesan atau kegagalan perusahaan Public relation fokus pada semua hubungan yang dilakukan organisasi dengan berbagai macam kelompok publik. Moriarty, dkk ( 2011: 616-618 ).

5. World of mounth ( Informasi Mulut ke Mulut )

Dalam hal ini peranan orang sangat penting dalam jasa. Pelanggan sangat dekat dalam penyampaian jasa. Lupiyoadi dan Hamdani ( 2009: 122 ).

6. Direct Marketing ( Pemasaran Langsung )

Pemasaran langsung merupakan unsur terakhir dalam bauran komunikasi dan promosi.

\section{METODE}


Adapun sumber data dari penelitian ini diperoleh dari Dinas Pariwisata dan Kebudayaan Kabupaten Kerinci, pegawai dan petugas yang ditunjuk.

\section{Alat analisis Data}

\section{Analisis SWOT}

(1) Strenght (kekuatan)

Adalah mengkaji ketentuanketentuan yang dimiliki oleh perusahaan , agar perusahaan selalu dapat mempertahankan kekuatan yang ada sehingga akan memiliki landasan yang kuat untuk menggariskan kebijakan yang akan ditempuh dan tidakan kebijakan pencapaian tujuan perusahaan. Seperti kekuatan produk, persaingan harga dll.

(2) Weaknesses (kelemahan)

Mengkaji kelemahan-kelemahan yang ada didalam perusahaan , agar perusahaan dapat menanggulanginya dn perusahaan dapat berjalan seperti yang diinginkan.

(3) Opprtunities (peluang)

Menganalisis dan melihat kondisi-kondisi yang dapat mendukung kemajuan dari perusahaan sehingga celah-celah tersebut dapat dimanfaatkan dengan sebaik-baiknya oleh perusahaan yang bersangkutan untuk mengembangkan usahanya atau menjadikan suatu kekuatan.

(4) Threats (ancaman)

Yaitu menganalisis kondisi yang dapat mengancam kehidupan perusahaan apabila tidak dapat diatasi dengan segera karena dapat mengganggu keadaan perusahaan. Ini berasal dari faktor ekternal yang lebih banyak karena hal ini sulit untuk diperkirakan seperti kondisi alam, pertumbuhan ekonomi dll.

\section{Matrik SWOT}

Matriks SWOT adalah alat yang dipakai untuk menyusun faktor-faktor strategi perusahaan. Matriks ini dapat menggambarkan secara jelas bagaimana peluang dan ancaman eksternal yang dihadapi perusahaan disesuaikan dengan kekuatan dan kelemahan yang dimiliki (Rangkuti, 2009). Matrik ini dapat menghasilkan empat set kemungkinan alternatif strategi.

Tabel 2

Matrik SWOT

\begin{tabular}{|l|l|l|}
\hline \multicolumn{1}{|c|}{ IFAS } & Kekuatan (Strength) & Kelemahan (Weakness) \\
\hline Peluang (Opportunity) & $\begin{array}{l}\text { STRATEGI SO } \\
\text { Ciptakan strategi yang } \\
\text { menggunakan kekuatan } \\
\text { untuk memanfaatkan } \\
\text { peluang }\end{array}$ & $\begin{array}{l}\text { STRATEGI WO } \\
\text { Ciptakan strategi yang } \\
\text { meminimalkan kelemahan } \\
\text { untuk memanfaatkan } \\
\text { peluang }\end{array}$ \\
\hline Ancaman (Threats) & $\begin{array}{l}\text { STRATEGI ST } \\
\text { Ciptakan strategi yang } \\
\text { menggunakan kekuatan } \\
\text { untuk mengatasi ancaman }\end{array}$ & $\begin{array}{l}\text { STRATEGI WT } \\
\text { Ciptakan strategi yang } \\
\text { meminimalkan kelemahan } \\
\text { dan menghindari ancaman }\end{array}$ \\
\hline
\end{tabular}


Sumber: Rangkuti (2009: 31)

Keterangan:

1) Strategi $\mathrm{SO}$

Strategi ini dibuat berdasarkan jalan pikiran perusahaan yaitu dengan memanfaatkan seluruh kekuatan untuk merebut dan memanfaatkan peluang sebesar mungkin.

2) Strategi $S T$

Strategi ini dibuat berdasarkan bagaimana perusahaan menggunakan kekuatan yang dimiliki untuk mengatasi ancaman

3) Strategi WO

Strategi ini diterapkan berdasarkan pemanfaatan peluang yang ada dengan cara meminimalkan kelamahan yang ada.

4) Strategi WT

Strategi ini didasrkan pada kegiatan yang bersifat defensif dan berusaha meminimalkan kelemahan yang dimiliki perusahaan serta menghindari ancaman yang ada.

\section{HASIL}

\section{SWOT}

a) Kekuatan.

Kekuatan apa saja yang dimiliki pariwisata. Dengan mengetahui kekuatan, pariwisata dapat dikembangkan menjadi lebih tangguh hingga mampu bertahan dalam pasar dan mampu bersaing untuk pembangunan selanjutnya.

b) Kelemahan

Kelemahan adalah sesuatu faktor yang tidak menguntungkan atau merugikan bagi pariwisata kabupaten kerinci.

c) Peluang

Peluang adalah kecendrungan lingkungan yang menguntungkan yang dapat

meningkatkan pariwisata kabupaten kerinci menjadin lebih baik dan berkembang.

d) Ancaman

Ancaman adalah hal-hal yang dapat mendatangkan kerugian bagi pariwisata, seperti praturan pemerintah yang tidak memberikan memberikan kemudahan berusaha, rusaknya lingkungan, penularan penyakit Aids, meningkatnya pelacuran, atau gejolak sosial sebgai akibat mahalnya dan persaingan tour operator asing yang lebih profesional.

\section{Analisis SWOT}

Faktor internal dan eksternal Dinas Pariwisata dan Kebudayaan kabupaten kerinci adalah sebagai berikut:

a. Kekuatan

Kekuatan apa saja yang dimiliki pariwisata. Dengan mengetahui kekuatan, pariwisata dapat dikembangkan menjadi lebih tangguh hingga mampu bertahan dalam pasar dan mampu bersaing untuk pembangunan selanjutnya. Kekuatan pariwisata kabupaten kerinci yaitu :

1. Wisata alam yang bisa dijadikan sebagai Outbond yang sangat bangus.

2. Banyak bekerja dan bermata pencaharian dari wisatawan, seperti untuk menjadi pemandu untk wisatawan asing.

3. Tersedianya beberapa homestay ditempat wisata alam.

4. Pemerintah yang sangat memperhatikan ditempattempat wisata alam.

b. Kelemahan. 
Kelemahan adalah sesuatu faktor yang tidak menguntungkan atau merugikan bagi pariwisata. Kelemahan-kelemahan

pariwisata kabupaten kerinci yaitu :

1. Kurangnya SDM yang memadai

2. Infastruktur yang kurang memadai untuk objek wisata alam.

3. Belum ada hotel-hetel berbintang untuk penginapan wisatawan.

4. Akses yang jauh.

c. Peluang

Peluang adalah kecendrungan lingkungan yang menguntungkan yang dapat meningkatkan pariwisata kabupaten kerinci, peluang pariwisata kabupaten kerinci yaitu :

1. Banyaknya tempat pariwisata dikabupaten kerinci sangat banyak dan terkenal di mancanegara.

2. Wisata alam yang ada di kabupaten kerinci sangat unit dan menarik untuk dikunjungin

3. Cindera mata yang khas dan unik dari kerajinan asli budaya kerinci.

4. Pusat kota yang kecil, sehingga tidak banyak mengeluarkan biaya transportasi dalam kota.

d. Ancaman

Ancaman adalah hal-hal yang dapat mendatangkan kerugian bagi pariwisata, seperti praturan pemerintah yang tidak memberikan memberikan kemudahan berusaha, rusaknya lingkungan, penularan penyakit Aids, meningkatnya pelacuran, atau gejolak sosial sebgai akibat mahalnya dan persaingan tour operator asing yang lebih profesional. Bebrapa ancaman yang dapat mengancam pariwisata kabupaten kerinci yaitu : (1) transportasi udara yang sering tidak aktif; (2) Trnsportasu darat yang berjarak jauh dari ibu kota provinsi; dan (3) banyaknya pengerusakan tempat wisata oleh manusia itu sendiri.

\section{SIMPULAN}

Berdasarkan hasil penelitian dapat disimpulkan sebagai berikut:

1. Hasil prosedur dari analisis SWOT terhadap dinas pariwisata dan kebudayaan kabupaten kerinci berada pada kuadran 1 (positif,positif) yang berarti keunggulan kompotitif atau strategi agresif dari dinas pariwisata dan kebudayaan kabupaten kerinci memiliki kekuatan serta peluang yang cukup untuk terus meningkatkan promosi agar mempernperbesar jumlah kunjungan wisatawan ke kabupaten kerinci.

2. Strategi pemasaran yang tepat diterapkan dinas pariwisata kabupaten kerinci untuk saat ini adalah strategi SO (strength, Opportunities). Strategi ini dilakukan untuk memanfaatkan kekuatan guna untuk menagkap peluang yang dimiliki. Strategi yang dapat diterapkan adalah sebagai berikut : (a) Dinas pariwisata kabupaten kerinci harus tetap berupaya mengembangkan pariwisata di kabupaten kerinci; (b) Dinas pariwisata kabupaten harus mengontrol pariwisata dengan baik; (c) Kordinasi dinas pariwisata dengan pemerintahan kabuapeten kerinci harus terus ditingkatkan; (d) Pelayanan yang diberikan harus terus ditingkatkan; dan (e) Untuk 
menambahkan kunjungan wisatawan ke kabupaten kerinci, dinas pariwisata dan kebudayaan harus memanfaatkan teknologi dan fasilitas yang tersedia, melakukan Promosi, dan sosialisasi sebanyak-banyaknya kepada masyarakat untuk meraih.

\section{DAFTAR PUSTAKA}

Alma Buchari, 2008 Manjemen Pemasaran dan Pemasaran jasa, Bandung CV Alfabeta.

Hoehastanty Jenny, 2007 Strategi Pemasaran wisata alam untuk meningkatkan Kunjungan wisatawan ke kabupaten kediri, Jurnal Ilmiah.

Amstrong dan Kotler Dasar-dasar Pemasaran Edisi kesembilan.

Yoeti, 2006 ; 237, Bauran Pemsasaran .

David, R, Fred, 2008;8 Organisasi dalam Bisnis. Edisi ke dua

Kotler, P, Gary, A, 2008, PrinsipPrinsip Pemasaran ,Erlangga, Jakarta

Tjiptono, F, 2008.Strategi Pemasaran. Andi Yogyakarta.

Purwanto, Irwan 2008, Manajemen Strategi, Bandung : Yrama Widya.

Rangruti, Freddy 2008, Analisis Swot Teknik Membedah Kasus Bisnis, Jakarta ; PT Gramedia Pusat Utama Jakarta. 